(2) Open Access Full Text Article

\title{
Poststreptococcal keratouveitis associated with group $C$ streptococcus pharyngitis
}

This article was published in the following Dove Press journal:

Clinical Ophthalmology

2 September $201 \mathrm{I}$

Number of times this article has been viewed

\author{
Nathaniel Nataneli' \\ Zenia P Aguilera' \\ Pearl S Rosenbaum' \\ Tamar Goldstein ${ }^{1,2}$ \\ Martin Mayers' \\ 'Department of Ophthalmology, \\ Bronx-Lebanon Hospital Center, \\ Albert Einstein College of Medicine, \\ Bronx, NY, USA; ${ }^{2}$ Sackler School \\ of Medicine, Tel Aviv University, \\ Tel Aviv, Israel
}

Correspondence: Pearl S Rosenbaum Bronx-Lebanon Hospital Center, Department of Ophthalmology,

Suite IC, 1650 Selwyn Avenue,

Bronx, NY 10457, USA

$\mathrm{Tel}+\mathrm{I} 7189602040$

Fax +I 7I8960 2045

Email psr_eyemd@yahoo.com
Purpose: To report the first case of poststreptococcal syndrome uveitis (PSU) in association with group C streptococcus (GCS).

Patients and methods: Chart review of a 24-year-old man who presented with bilateral ocular redness, pain, and photophobia for 5 days and "white rings" around his eyes for a duration of 3 days. The patient further reported fever and sore throat in the preceding week. Slit-lamp examination showed bilateral keratouveitis. A thorough uveitis workup, antistreptolysin $\mathrm{O}$ (ASLO) titer, and throat culture were obtained. The patient was treated with frequent topical steroids and systemic doxycycline. The uveitis and keratitis subsided over the next few weeks, leaving extensive peripheral keratolysis.

Results: The results of laboratory diagnostic testing revealed an elevated ASLO, C-reactive protein, as well as HLA-B27 positivity. Throat cultures grew beta-hemolytic GCS; group A streptococcus was culture negative.

Conclusion: GCS pharyngitis may be a causative organism of PSU.

Keywords: pharyngitis, keratolysis, keratouveitis

\section{Introduction}

Poststreptococcal syndrome uveitis (PSU) is a rare complication of pharyngitis. PSU was first described in 1991, ${ }^{1}$ and has since been reported only in association with group A streptococcus (GAS).

\section{Material and methods}

A chart review was performed on a 24-year-old man with no past ocular history, who presented with bilateral ocular pain, redness, and photophobia for 5 days as well as "white rings on the eyeballs" for 3 days. Symptoms in each eye began within 1 hour of each other. He denied contact lens use. The patient reported a 2-week history of sore throat, fevers $\left(\mathrm{T}_{\max }=102^{\circ} \mathrm{C}\right)$, and malaise. He denied shortness of breath, joint pain, weight loss, unexplained fevers, rashes, ulcers, hematuria, or previous similar ophthalmologic episodes. He denied any contact with animals. Past medical history included idiopathic seizure disorder and allergy to penicillin.

Ophthalmologic examination revealed best-corrected visual acuities of 20/25 in each eye. Slit lamp biomicroscopy showed bilateral conjunctival injection and extensive peripheral corneal infiltrates, sparing the limbus (Figure 1). No corneal staining or thinning was noted. Small, white keratic precipitates were present diffusely. The anterior chambers had $2+$ and $3+$ cells in the right and left eyes, respectively. No iris nodules or synechiae were noted. Dilated fundus examination was unremarkable. 


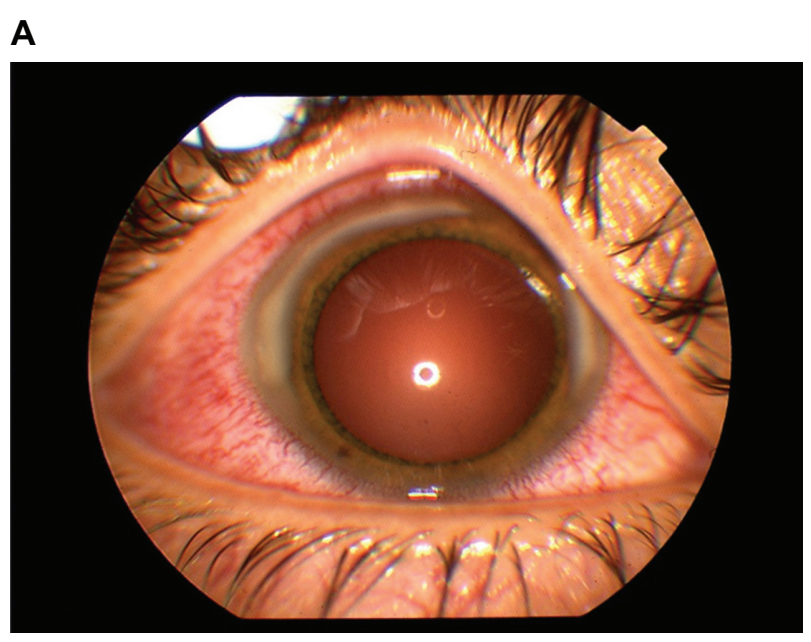

B

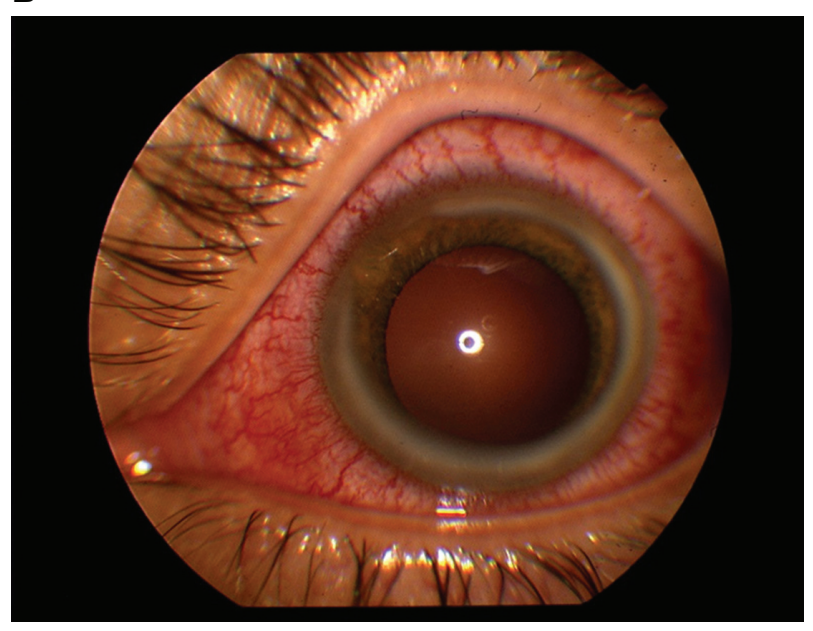

Figure I External photographs of the right (A) and left (B) eyes, showing marked conjunctival injection and extensive peripheral corneal infiltrates.

\section{Results}

The results of laboratory investigations, including antineutrophil cytoplasmic antibody, angiotensin-converting enzyme, antinuclear antibody, Lyme screen, rheumatoid factor, and syphilis testing were all within reference ranges. HLA-B27, however, was positive, and C-reactive protein $(1.7[<0.8 \mathrm{mg} / \mathrm{dL}])$ and ASLO $(390[\leq 200 \mathrm{IU} / \mathrm{mL}])$ were elevated. Urinalysis performed 2 days and 3 weeks after presentation revealed no red blood cells or casts. Throat culture was positive for beta-hemolytic group $\mathrm{C}$ streptococcus (GCS), but not for GAS.

The patient was initially treated with topical prednisolone acetate $1 \%$ hourly, ofloxacin $0.3 \%$ four times a day, and cyclopentolate $1 \%$ twice a day to both eyes. Because of concern for impending keratolysis, doxycycline $100 \mathrm{mg}$ orally twice a day was initiated for its antimetalloprotease properties. In light of the elevated ASLO titer and growth of
GCS in throat culture, doxycycline was further continued for its antistreptococcal activity.

Over the next few days, the patient's symptoms and anterior uveitis subsided. The circumferential corneal infiltrates improved significantly over a period of 4 weeks, leaving marked corneal thinning peripherally which has remained stable after more than 9 months follow-up. By the sixth week after presentation, no ocular inflammation was noted and the best corrected visual acuities improved to $20 / 20$ bilaterally.

\section{Discussion}

PSU is a rare complication of pharyngitis. Since PSU was first described in 1991, ${ }^{1}$ it has only been reported in association with GAS. In the most complete review to date of PSU in the world literature, Rehman et al described a median lag of 10 days between the onset of pharyngitis and uveitis (range 1-6 weeks). ${ }^{2}$ Systemic evidence of streptococcal disease is highly suggestive of PSU. ${ }^{2}$ A nongranulomatousappearing bilateral uveitis in a patient under the age of 40 years is strongly consistent with the typical features reported in this series. ${ }^{2}$ In six of ten cases reported in the aforementioned study, no posterior segment involvement was found. In the other four cases, however, vitritis, cotton wool spots, optic disk swelling, Roth spots, retinal hemorrhages, vitreal snowballs, retinitis, or multifocal choroiditis were observed. ${ }^{2}$ A more recently published case series described a similar spectrum of ocular involvement, adding that posterior synechiae may also be present. ${ }^{3}$ Although keratic infiltrates were not described as a feature in these reports, another report described a woman with necrotizing keratitis in the context of PSU. ${ }^{4}$

Our patient's clinical and laboratory features are remarkably consistent with those described in PSU associated with GAS. We do not believe that our patient had isolated HLA-B27 uveitis, which is typically unilateral in presentation, ${ }^{5}$ although this genotype may have predisposed him to inflammatory phenomena, in this case to PSU. This concept is established, as patients exhibiting HLAB27 positivity have been described with poststreptococcal reactive arthritis. ${ }^{6}$

Though much less frequently associated with post infectious immune phenomena than GAS, GCS has been reported to cause postinfectious inflammatory syndromes, namely poststreptococcal glomerulonephritis ${ }^{7,8}$ and poststreptococcal reactive arthritis. ${ }^{9}$ Furthermore, it has been demonstrated that GCS, like GAS, may exhibit 
the $\mathrm{M}$ protein in its cell wall, ${ }^{10}$ which has been shown to possess superantigenic properties. ${ }^{11}$ It is thus reasonable to believe that GCS, like GAS, may also lead to postinfectious uveitis.

\section{Conclusion}

GCS may cause PSU as well as keratitis in a pattern similar to that which occurs in the GAS-associated syndrome. Keratolysis is an additional clinical feature described herein as an ocular sequela of GCS keratouveitis. Clinicians should be aware of GCS's potential to incite systemic and ocular immunologic phenomena, and should include GCS-associated PSU in the differential diagnosis of keratouveitis.

\section{Disclosure}

The authors report no conflicts of interest in this work.

\section{References}

1. Cokington CD, Han DP. Bilateral nongranulomatous uveitis and a post streptococcal syndrome. Am J Ophthalmol. 1991;112(5):595-596.

2. Rehman S, Anand S, Reddy A, et al. Post streptococcal syndrome uveitis: a descriptive case series and literature review. Ophthalmology. 2006;113(4):701-706.
3. Tinley C, Van Zyl L, Grötte R. Poststreptococcal syndrome uveitis in South African children. Br J Ophthalmol. 2011. [Epub ahead of print].

4. Papageorgiou KI, Ioannidis AS, Andreou PS, Sinha, AJ. Optic atrophy, necrotizing anterior scleritis and keratitis presenting in association with Streptococcal Toxic Shock Syndrome: a case report. J Med Case Reports. 2008;2:69.

5. Suhler EB, Martin TM, Rosenbaum JT. HLA-B27-associated uveitis: overview and current perspectives. Curr Opin Ophthalmol. 2003;14(6):378-383.

6. Mackie SL, Keat A. Poststreptococcal reactive arthritis: what is it and how do we know? Rheumatology (Oxford). 2004;43(8):949-954.

7. Barnham M, Thornton TJ, Lange K. Nephritis caused by Streptococcus zooepidemicus (Lancefield group C). Lancet. 1983;1(8331):945-948.

8. Thorley AM, Campbell D, Moghal NE, Hudson S. Post streptococcal acute glomerulonephritis secondary to sporadic Streptococcus equi infection. Pediatr Nephrol. 2007;22(4):597-599.

9. Jansen TL, Janssen M, Traksel R, de Jong AJ. A clinical and serological comparison of group A versus non-group A streptococcal reactive arthritis and throat culture negative cases of post-streptococcal reactive arthritis. Ann Rheum Dis. 1999;58(7):410-414.

10. Bisno AL, Collins CM, Turner JC. M proteins of group C streptococci isolated from patients with acute pharyngitis. $J$ Clin Microbiol. 1996;34(10):2511-2515.

11. Phillips GN Jr, Flicker PF, Cohen C, Manjula BN, Fischetti VA. Streptococcal M proteins: alpha helical coiled coil structure and arrangement on the cell surface. Proc Natl Acad Sci U SA. 1981;78(8): $4689-4693$.
Clinical Ophthalmology

\section{Publish your work in this journal}

Clinical Ophthalmology is an international, peer-reviewed journal covering all subspecialties within ophthalmology. Key topics include: Optometry; Visual science; Pharmacology and drug therapy in eye diseases; Basic Sciences; Primary and Secondary eye care; Patien Safety and Quality of Care Improvements. This journal is indexed on

Submit your manuscript here: http://www.dovepress.com/clinical-ophthalmology-journal

\section{Dovepress}

PubMed Central and CAS, and is the official journal of The Society of Clinical Ophthalmology (SCO). The manuscript management system is completely online and includes a very quick and fair peer-review system, which is all easy to use. Visit http://www.dovepress.com/ testimonials.php to read real quotes from published authors. 